Portland State University

PDXScholar

4-1970

\title{
Attitudes of Youth Toward Social Institutions: a Comparative Study
}

Connie McGonigle

Portland State University

James F. Bakke

Follow this and additional works at: https://pdxscholar.library.pdx.edu/open_access_etds

Part of the Social Work Commons

Let us know how access to this document benefits you.

\section{Recommended Citation}

McGonigle, Connie and Bakke, James F., "Attitudes of Youth Toward Social Institutions: a Comparative Study" (1970). Dissertations and Theses. Paper 732.

https://doi.org/10.15760/etd.732

This Thesis is brought to you for free and open access. It has been accepted for inclusion in Dissertations and Theses by an authorized administrator of PDXScholar. Please contact us if we can make this document more accessible: pdxscholar@pdx.edu. 
ATTITUDES OF YOUTH TOWARD SOCIAL INSTITUTIONS

A Comparative Study

Connie McGonigle Research Practicum April, 1970 


\section{INTRODUCTION}


In August, 1968, after a series of confrontations in the city parks between young dissidents and the police, the Mayor of Portland called upon the Metropolitan Youth Commission to form a special study committes to explore the areas of conflict and to recommend ways in which municipal government might constructively respond to the young people in the community. The independent research project on the alienation of youth, the results of which are reported here, was an outgrowth of the interest generated by the request from the office of the Mayor. Under the auspices of the Metropolitan Youth Comrission (MYC), a special office within the executive branch of city government concerned with the needs of youth, a questionnalre was constructed measuring both the attitudes of young people toward established social institutions and measuring the degree of personal alienation of the respondent. A research-consultant from the-Department of Psychiatry of the University of Oregon Medical School, Dr. John Marks, directed the development of the questionnaire. The-items-acuring personal alienation have been drawn from the "alienation eluster" on a scale constructed and refined by Chein and Associates in their roseareh on juvenile heroin addiction in New York City. In addition, items were included which would provide substantial information on personal background of the individual, e.g. family cohesiveness, social class, delinquent history, and drug use.

In spring, 1969, data was collected in four high schools in the metropolitan area (pop. 380,000 ). The student members of the MYC arranged for students in each school to distribute the questionnaires in classrooms and to enterpret the nature and purpose of the research project to those in the sample populations. Student rather than teacher-administration of the questionnaire was considered 
an important factor in assuring those participating of the confidentiality of Individual responses. However, since the students were free to select the specific classes to be sampled, the population was not careful]y randomized. The questionnalre was also completed by a small number of persons who were contacted at the Charix Coffee Hoise, a popular meeting place for young people identified with the city's hipple commutty. The Charix sample permits a comparison of the attitudes of those still attending school with a slightly older group of peers who have "dropped out" of the mainstream of communty life.

In the fall of 1969 , when the present writers became involved in the project, the research sample was extended to include a fifth public high school and a special ungraded secondary school, Vocational Village, whose enrollment includes high school drop-outs and youth referred by school or jurenile court officials. The respondents from the fifth high school were a random sample of the total school population which, in turn, is a cross-section of the middle and lowerincome groups in this community. The composition of this school and unique features of its program will be more fully described in a later section of this paper. The sample drawn from Vocational Village is also considered unbiased because the questionnaire was administered in English classes, a required subject for all enrollees.

The data collected during the two time periods, spring 1969 and fall 1969, has been analyzed spparately. Since the four schools of the original sample differ in terms of the ethnic and socio-economic status of their enrollments, a comparison of responses by schools to ascertain relationships between soctal status and alienation has been a major focus of the data analysis. Factual information about the socio-economic characteristics of the individual schools 
has been drawn from city census reports and research conducted by Portland's School District \#1. 


\section{PART I}

SOCTO ECONONIC CONDITIONS OF AREAS UNDER STUDY and THEIR RELATIONSHIP TO ALIENATION SCORES

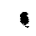


In the following section, the four schools from which samples were drawn for the first phase of the study will be compared in terms of the socio-economic characteristics of their respective geographic areas. From the information available, it is possible to rank the schools according to the prevalence of disadvantageous conditions and then to consider the responses on the questionnaire in terms of this ranking.

Jefferson High School's geograhple boundaries encompass an area that has the greatest prevalence of negative conditions of the areas under study. Thirteen percent of the area's residents are non-white. There is a higher concentration of Negroes in parts of the Jefferson district than in any other section of the city (with the exception of a small area within Grant High School's boundaries to be considered later). Income is under $\$ 3000$ for $17 \%$ of Jeffersonarea families. I In 1967, a study by School District indicated that there were more students at Jefferson whose families were receiving welfare assistance (10.8\%) than in any other school in the district. 2 These figures would not have changed appreciably before the present research was undertaken. The Jefferson area is fairly homogeneous in regard to income since the great majority of its families have modest incomes. There are proportionately fewer families with an annual income in excess of $\$ 10,000$ than in the other three schools' areas; in only three of this section's twelve census tracts does the number of families who enjoy this comparative affluence approach twenty percent. ${ }^{3}$ Finally, there are also more pockets of high juvenile and adult crime rates within this school's boundaries. 4

The Grant High School area is the most heterogeneous in the study, largely because it includes two census tracts at its western boundary, where it touches the Jefferson district, which compose the core area of Portland's ghetto (Albina). 
One of these, tmact $23 \mathrm{~A}$ (pop. 3247 ) is distinguished by having a high incidence of every negative social phenomenon measured by city and county research groups after the 1960 census. For exemple, in one-third of the area, 15-19 persons per thousand recelve Aid to Dependent Children. In another one-third of the tract, the ADC rate per thousand is 10-14 persons. One-half of $23 \mathrm{~A}$ has an adult crime rate of 15 per 1000 persons, the highest measured rate in any residential area, and one-quarter of the tract has a 5-9 per 1000 persons crime rate. ${ }^{5}$ The non-white population of the Grant area as a whole is less than $1 \%$, but most of the Hegro families are clustered in the very low income area described above or in the neighborhoods immediately east of it. ${ }^{6}$ In contrast to $23 \mathrm{~A}$ and parts of the tracts adjacent to-tb, most of the Grant district has lower rates of crime and fewer welfare recipients than many areas of the city. School District \#'s research found that only $1.1 \%$ of the Grant student body received welfare aid. 7 There are also several upper-income neighborhoods that contrast sharply with the ghetto area from which Grant also draws students. In two of the area's fourteen census tracts, over $30 \%$ of the families have income in excess of $\$ 10,000$, and in several other neighborhoods over $20 \%$ of the families have a comparable income. 8 In the entire area, 10\% of the families have income under $\$ 3,000$. Parkrose, which is located in the northeast comer of the clty and has an autonomous school administration, is a middle-to-low income area which is ractally homogeneous. It had roughly the same proportions of porerty and affluence in 1960 as the Grant area. Only $12 \%$ of the families have income under $\$ 3000$, but in only one of its five census tracts do as many as $30 \%$ of the families have income over $\$ 10,000$. While recent census data is unavallable, we know that Negro families have been moving eastward into the Grant area as the Negro population has expanded. It is therefore supposed that $G$ rant now has a higher 
proportion of low income families than Parkrose. The fact that the Parkrose area had a much smaller rate of change of residence in the five years preceding the census than any of the other areas would seem to reflect greater stability and perhaps greater insulation from the social forces bringing change to other parts of Portland. 9

Wilson High School is located in a comparatively new residential area on the west side of the city. As Table I illustrates, the Wilson area has only negligible rates of those conditions that are associated with residential blight. In four of the five census tracts in that district, over $30 \%$ of families have incomes in excess of $\$ 10,000$ per year. In a ranking of the schools in the study on the basis of freedom from disadvantageous social and economic conditions, Wilson High School is first follwed by Parkrose, Grant, and Jefferson in that order.

$$
\text { Table I } 10
$$

Socio-Economic Conditions by School Areas

I.

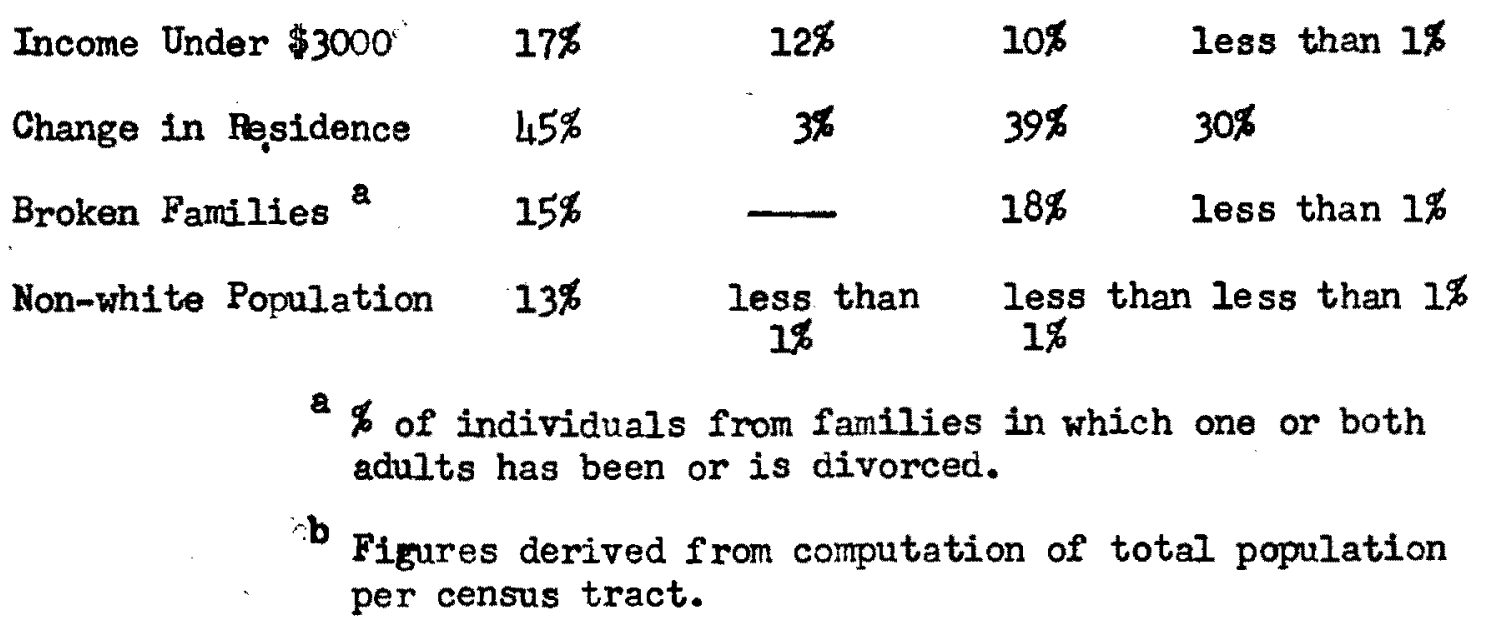


Hypothesis th was that the profiles of scores on the questionnaire in Individual schools would reflect a positive relationship between favorable socio-economic conditions within the school's boundaries and attitudes toward social institutions. Further, it was hypothesized that negative attitudes would be expressed more often in schools whose students were drawn from the economically disadvantaged areas of the city. "Disadvantaged areas" were defined as those with the highest incidence of: 1) incomes under $\$ 3000$, 2) broken families, 3) non-white population, 4) families receiving $A D C$, and 5) adult and juvenile crime. )

Before considering the differences in responses among the schools, the characteristics of the entire sample from four schools will be reviewed. The mean age of the 488 subjects was 16.7 years, and the sample population was 58.4\% female. The mean grade level completed was 10.8 with $15 \%$ having completed the 9 th and 10th grades, $30 \%$ having completed the 1 th grade, and $33 \%$ having finished the twelfth. 11 In the first part of the questionnaire, which sought to measure social alienation, students were asked to indicate what they thought of each social group or institution listed. Possible responses were "Good", "Somewhat Good", "Don't Care", "Somewhat Bad", and "Bad". These responses were ranked for machine scoring with "Good" assigned four points, "Bad" assigned zero points, and 2.00 representing the neutral position.

The most favorable attitudes were toward parents for whon the mean score was 3.4 (slightly better than "Somewhat Good"). "Your city" and the FW/YMCA also received comparatively positive ratings. Table II illustrates the order In which each school and the alienated group from the Charix ranked the institutions in terms of positive attitudes. The mean responses of the total sample are included as a base of comparison. While no institution is given a negative 


\section{Table II}

Ranking of Mean Responses Reflecting Attitudes Toward Social Institutions

Total Grant PR Jeff Wilson Charix

$\begin{array}{lllllll}\text { Armed Forces } & 2.32 & 2.49 & 2.55 & 2.45 & 1.86 & \begin{array}{c}\text { (alienated) } \\ 1.29\end{array} \\ \text { City Officials } & 2.38 & 2.66 & 2.49 & 2.40 & 2.16 & 1.00 \\ \text { U.S. Govt } & 2.57 & 2.79 & 3.09 & 2.46 & 2.17 & 1.62 \\ \text { Police } & 2.57 & 2.76 & 2.79 & 2.47 & 2.48 & 1.62 \\ \text { Older Generation } & 2.74 & 2.93 & 2.90 & 2.59 & 2.66 & 2.35 \\ \text { Boy/Girl Scouts } & 2.83 & 2.92 & 2.86 & 2.82 & 2.71 & 2.70 \\ \text { School } & 2.88 & 3.15 & 3.13 & 2.31 & 3.28 & 2.33 \\ \text { Ghurcines } & 2.98 & 3.05 & 2.99 & 3.09 & 2.78 & 2.62 \\ \text { Business } & 2.98 & 3.24 & 2.98 & 3.05 & 2.70 & 2.10 \\ \text { IM/YwCA- } & 3.08 & 3.23 & 2.90 & 3.13 & 3.02 & 2.79 \\ \text { Your city } & 3.14 & 3.37 & 3.26 & 3.00 & 3.17 & 1.85 \\ \text { Iour parents } & 3.44 & 3.49 & 3.51 & 3.47 & 3.39 & 3.20\end{array}$

ranking by the total sample, i.e. less than 2.00 , the attitudes toward many do not reflect unqualified enthusiasm. (On the other hand, as Table II indicates, the attitudes of the alienated in the sample are markedly more negative than the total group's. It is significant, however, that the alienated tend to be most negative toward those institutions that are looked upon least favorably by the total group.) The only great difference in the rank order of opinion is in regard to the way in which the two groups view "your city", the alienated group being significantly less positive than the total sample. In the case of both groups, more positive attitudes are attached to groups with which the youth have had the most personal contact and the most negative toward institutions 
more remote in their individual experience, e.g. Armed Forces, City officials, U.S. govermment.

Item \#II, which asked about attitudes toward hippies, has been excluded from the analysis of attitudes of social alienation illustrated in Table II because hippies do not represent an established social group comparable to the others on the questionnaire. The mean response of the total group to this item was 1.70. The alienated group's response was 3.2 , reflecting this group's strong identification with the hippie subculture.

In regard to the differences among schools, Jefferson students, the most disadvantaged of the subsemples, and Wilson students, who represent the most advantaged group, were similar in showing the least favorable attitudes among the four schools. Whereas this was the expected result for Jefferson students, It is the reverse of what was expected from the Wilson group. Thus, Hypothesis H1 is disconfimed, and its reverse can be asserted: the most advantaged students show the greatest alienation from societal values. However, the lack of consistency in results of the questionnaire means that this assertion cannot be made unequirocally. "Grant High School students registered the most favorable attitudes. The research hypothesis anticipated much more similarity in attitude between Grant and Wilson students than actually resulted.

Looking first to the ways in which Grant students' more positive attitudes differed from those of students in other schools, the data indicates that there was less difference between Grant and Parkrose than between Grant and any other school. Student's t-test has been used to compute statistically significant differences at the .05 level of confidence. Differences were significaint at the .05 level only in Grant students' more positive attitudes toward business 
and Industry and the MM/YWCA. Grant and Wilson differed significantly on five items: the Armed Forces, older generation, U.S. government, business and industry, and city officials. Grant students saw the institutions in general as "Somewhat Good" with only a few mean responses falling into the "Don't Care", category. Grant and Jefferson differed on most of the same items that Wilson and $G_{\text {rant }} d i d$, and $G_{\text {rant }}$ was also significantly more positive that Jefferson toward "your school" and "your city". (See Table III)

The greatest differences were between $G_{r a n t}$ and the alienated group. The only items on which Grant students did not register significantly more positive feelings were the ones on church, parents, and Boy/Girl Scouts. The attitudes of Grant students and Chairix respondents were most polarized on the subjects of "your city", hippies, and business and industry. The mean response to the item on hippies at Grant was 1.81 , which was considerably more negative than the attitudes expressed toward any of the established groups.

Parkrose rated the Ary and the U.S. government significantly more favorably than did Wilson students. Like Grant, Parkrose dfffers more with Charix group than with any of the other schools. There were significant differences between Grant and the Charix on ten items; Parkrose differs from the Charix on nine items.

Table II indicates that of the four schools, Wilson's attitudes toward established institutions were least favorable. Jefferson would be ranked next, and the differences in mean responses between Wilson and Jefferson are very slight on several items. In contrast to the pattern observed with Grant and Parkrose, there are significant differences between wilson and the Charix on fewer items than between the Charix and any of the other three schools. Wilson and Jefferson differ significantly on only four items. Wilson students gave 


\section{Table III}

Significant Differences in Attitude Toward Social Institutions ( quoted in " $t$ " scores)

\begin{tabular}{|c|c|c|c|c|c|c|c|c|c|c|}
\hline Item & G-PR & G_W & Q.J & G.C & PR W & PRnJ & $\mathrm{PR}-\mathrm{C}$ & $\mathrm{W}-\mathrm{J}$ & $W-C$ & J_C \\
\hline Arruy & & 3.18 & & 3.53 & 3.27 & & 3.79 & -3.19 & & 3.66 \\
\hline City Off. & & 3.40 & 2.03 & 6.94 & & & 5.59 & & 4.09 & 5.29 \\
\hline v.s. Govt & & 3.70 & 2.22 & 3.90 & 5.26 & 3.83 & 5.22 & & & 2.69 \\
\hline Police & & & & 3.69 & & & 3.52 & & 2.65 & 2.71 \\
\hline 0ld. Gen & & 2.20 & 2.78 & 2.45 & & 2.11 & 2.19 & & & \\
\hline
\end{tabular}

Scouts

School

$5.90 \quad 3.07$

$\begin{array}{llll}5.06 & 2.94 & 6.33 & 3.85\end{array}$

Churches

$4.43 \quad 2.39 \quad 5.02$

$-2.03$

$B$ and $I$

2.52

1.99

BM/TWCA

2.32

3.196 .64

5.62

5.45

4.34

Parents

Note: Negative t-scores indicate that the first of the two schools had a less favorable mean response than the second school.

J-Jefferson, G-Grant, PR-Parkrose, W-Wilson, 6-Charix

their school a mach more positive rating than did Jefferson's but were more negative toward the army, church, and business and industry. In both wilson and Jefferson responses, it is to be noted that, oven when they are signif1cantly more positive than the aljenated group, the degree of difference is often not as great as is the case with Grant and Parkrose responses./ For example, $t=5.45$ between Wilson and the Charix on attitude toward "your city", and $t=6.64$ between Grant and the Charix on the same item. On the item about attitudes toward police, there are no significant differences among the four schools, but each of the schools differs significantly with the more negative Charix group. 
CONCLUSIONS TO PART I 
The fact that students from the most disadvantaged area consistently registered negative attitudes, at least in comparis on to two of the other schools, was an expected result of the research. It is interesting to note that this occured despite the fact that special variables aimed at influencing attitudes have been in operation at Jefferson High School. Jefferson was Identified by the school district as a "trouble spot" several years ago because of interracial conflict between students, more severe disciplinary problems than in other city high schools, and some highly publicized fights allegedly started by Jefferson students during athletic meets in other parts of the city. When federal funds became available under Title $I$ of the Aid to Elementary and Secondary Schools Act, the school district inaugurated a special program at Jefferson to promote attitudinal change. One of the major goals toward which district officials report there has been substantial progress is in improving communication and understanding between students, faculty, and parents. Parental involvement in school affairs has been achieved by employing these parents in part-time jobs as teachers' assistants, tutors, etc. An Interpersonal Relations Project has made funds available for regular student/faculty retreats, and the traditional curriculum has been broadened to include classes that attract the interest and committment of more students. The guidance staff includes a clinical psychologist, and more intensive diagnostic and counseling services are available for students. These and other facets of the program have been part of a concerted effort to alter the image of Jefferson held both by adults and adolescents who are part of it and in the wider community. 
The fact that attitudes at Jefferson are as positive as they are may reflect the effects of this program. An interpretation of the results of the present research should at least acknowledge the possible influence of this special "attitudinal change" program. That is, Jefferson students could be as positive in outlook on social institutions as they are not because of but in spite of the relative deprivation of the families in the area. Unlike students in many disadvantaged areas, those currently enrolled at Jefferson have been experiencing expensive and innovative educational programs under the direction/ of some of the most highly qualified teachers and administrators in the district. Their feelings, which are not as negative as expected, may therefore reflect not what is typical but what is possible, 1.e. deprived youngsters who might otherwise develop feelings of isolation and hostility will respond at least neutrally toward the establishment when such an identification is facilitated by new opportunities.

Oottlieb's study of the recational and social aspirations of poor youth in three Easterm urban areas (1968) seems to support this interpretation. He contends that the alienation of poor and middle-class adolescents must be distinguished in terms of the cause of withdrawal. The middle-class youngster rejects what he sees as a crass, commercial culture, and "...the cholce of involvement or estrangement is usually with him." 12 In contrast, the lower class adolescent who adopts deviant behavior has been forced into this role because his opportunities for upward mobility are so limited. "The poor adolescent, and this is probably most true of urban Black males, does not reject the middle class style of Iiving.... Given the choice he would gladly exchange his current status with the disenchanted of Harvard, Vassar, and Yale."13 In Gottlieb's conclusions, he 
submits that poor youth want to be middle class:

"It is not I believe a question of a lower class value system or subculture which contains elements opposed to or in conflict with legitimate means and ends. It is not, as is frequently the case among middle class adolescents, an opposition to that life style which is called middle class. Rather, the poor adolescent finds hirself alienated because he is without resources and referents which have become increasingly important for goal attainment in our society." 14

While Jefferson High School students are probably not as poor as a group as were those in Gottlieb's study nor is the Portland ghetto as isolated a community as its counterpart in a larger metropolitan area, these youngsters and their families represent one of the most deprived groups in this community. The special educational program, which was initiated at Jefferson because of increasing tensions and undesirable behavior, made available some of the resources and referrents to which Gottlieb refers above. While there may be other determinants of the social attitudes of Jefferson students, the upgrading of the educational progrem within the last three years can be considered a major influence. On the other hand, the negative-leaning attitudes of Wilson students can be understood in terms of the phenomenon of middle-class alienation in which youth who can,afford the luxury of choice adopt attitudes even less favorable to the status quo than their more disadvantaged peers.

In respect to what conclusions are to be drawn about the comparatively positive attitudes of Grant students, it is observed that economic advantage is the characteristic that most distinguishes these from others in the sample. There is also more heterogeneity among the Grant population, ceitainly when it is compared with Wilson, and the broader base of comparison may influence Grant attitudes in a positive direction.

Considering the research results in broad, general terms, we find the most negative attitudes among those at either extreme of the socio-economic scale, i.e. 
among those who are economically able to exercise some choice in adopting or rejecting societal values and those who may feel relatively "locked out" of the system. However, a comparison of the attitudes of high school students to those of the alienated group at the Charix makes clear that the attitudes of even the most negative students are not "alienated". 


\section{FOONNOTES}

1. Portland's Residential Areas: An Initial Appraisal - Blight and Other Factors. Community Renewal Program. Portland City Planning Commission, Oct., 1965.

2. Unpublished information complled by the Research Division of the Administrative Offices of School District No. 1; Portland, Oregon.

3. Population and Housing (A Summary and Extension of Selected 1960 Census of Population and Housing Data by Census Tract for the Portland Standard Metropolitan Statistical Area) Metropolitan Planning Commission; Portland, Oregon, June, 1963.

4. Portland's Residential Areas, op. cit., no page reference.

5. Ibid.

6. Ibid.

7. School District Research, op. cit.

8. Population and Housing, op. cit.

9. Ibid.

10. Portland's Residential Areas, op. cit.

11. Since all respondents except the twenty at the Charix Coffee House were currently enrolled in school, $33 \%$ of the total sample could not have completed the twelfth grade. This figure is assumed to reflect a misinterpretation of the question by the respondents, i.e. those enrolled in the twelfth grade at the time of the data collection incorrectly indicated that they had completed that grade.

(12.) David Gottlieb, "Poor Youth: A Study in Forced Alienation," Journal of Social Issues, Vol. XXV, No. 2 (April, 1969), p. 92.

13. Ibid., p. 92 .

14. Ibid., p. 118 . 
ALIFNATED YOUTY

FART II

by:

JAMES F. BAKYE 
AIIENATJON AND DRUG USE IN THE FIR.ST SAMPLE

In part I of this paper data from Grant, Parkrose, Wilson, Jefferson and Charix were used. A further analysis of this samble's data investigated the correlates of alienation and of drug experience. Responses from the questionnaires were run through the computer three separate times.

The first two divisions were concerned with determining alienation. In division 1 institutional alienation was derived from the sum of items $5,7,8,9,10,11$ (scoring reversed so $4=0$, $3=1,2=2,1=3,0=4$, no response $=9$ ), $12,13,15,16$, and 17 . (see appendix for questionnaire) Two subsets were made, subset 1 being made up of those cases where the sum of the responses was equal to or less than 30, and subset 2 those cases where the sum was more than 30. Data on any case where any one of the items had no response were discarded. A score of 30 or less is considered to indicate alienation. The two subsets have been compared to determine "if a "profile" of the more alienated youth can be determined statistically.

In division 2 social alienation was derived from the surns of items 28,29 (scoring reversed so $3=0,2=1,1=2,0=3$, no response =9), 30,31 , and 32. (see appendix) Again two subsets were made, suoset 1 being those cases whose score was less than 8 , and subset 2 being those cases whose score was 8 or more. As before cases where any one of the items had no response were discarded. A score of 8 or more is considered to indicate alienation. The two subsets were then compared as in division 1. 
In the third division data from cases where the responses indicated drug usage were analyzed for the purpose of determining if the drue user has a "profile" that is alike or different from that of the non-user, the alienated, or the non-alienated. In this analysis, a drug user is considered to be a respondent who indicates taking drugs more than once.

\section{ANALYSIS OF DATA}

The responses of subset 1 were compared with those of subset 2 for each item. in all three divisions. For items 1, 3, 40, 431, 432, $433,434,435,436,437,438,439,440,470,471,472,473,474,475$, $476,477,478,479,480,71,72,74$, and for social alienation, the critical ratio (CR) was computed with $\mathrm{CR}=1.96$ being significant. For all other items cross tabulation subsets were made against the responses. Expected frequencies were computed for each cell using marginal proportions and $N$ for each item. The degrees of freedom were then computed for each of these chi-squares. The significance of chi-square was determined by reference to standard mathmatical tables. 


\section{ALIENATION}

When the responses of the institutionally alienated were compared with those of the socially alienated it was found that their was no significant difference between the two. Thus it appears that institutional and social alienation are essentially congruent. Therefore, for the balance of the report, while the Institutional alienation scores are used to determine the alienated, social alienation is included in the meaning of "alienation."

The alienated respondent is found to be older ( 16.89 years of ace as compared with 16.43), more likely to be a male, and somewhat farther along in school (11.03 srade level as compared with 10.74). He is more likely to come from Charix, wilson, or Jefferson, and less likely to be from Grant or Parkrose.

Ftems 5 through 17 inclusive (see appendix) neasured institutional alienation. The alienated resnondent was to a statistically sipnificant degree, more negative on all items except for rating the hippies better than did the non-alienated.

In the section on social alienation the alienated tend to agree that most people won't really do anything to make this a better world. They reject the idea that what parents want their children to do are for the child's own good. They do not reject the idea that most people would be better off if they were never horn. They arree that parents are always looking for things to nas their children about. 
Scores were also computed to indicate feelings of powerlessness and numbness. Powerlessness equals items 18 (reversed), 20 (roversed), 21, 24, and 26(reversed). (see appendix) Numbness equals items 19, 22, 23(reversed), 25, and 27(reversed). (see appenaix) Higher scores on each scale indicate increased feelings of powerlessness or numoness. Critical ratios were computed for these scores with a $C R=1.96$ being considered significant.

In comparing the relative feelines of powerlessness and numbness, the alienated person is found to feel less powerful and somewhat, but not significantly, more numb than the non-alienated. On individual items he feels that he understands why he does things, disagrees that what a person makes out of life deponds on him, tends to feel that life is boring, and that when trings go bad, he does not try harder.

The alienated youth is strongly in favor of legalizing marijuana and is also in favor of reducing the penalties for its use or possession.

If he had a personal problem, he is most likely to taik it over with a friend of the opoosite sex. The nor-alienated respondent indicates a preference for talking to a parent or a friend of his own age and sex.

The alienated go to church or to club meetings less frequently than the non-alienated. He is less likely to live at home with both parents, has been arrested more frequently, and is less likely to agree with his parents regarding gols for his future.

The drug usage section reveals that he is more frequently a user, 
especially of marijuana. He is also more likely to have used it in the last year and to have used it more frequentIy than the nonalienated. In addition, he is more likely to have used speed, hallucinogens, and opiates.

The alienated youth differs from the non-alienated in his views of community problems in that he is somewhat more concerned about a lack of recreational and cultural opportunities, greatly less concerned about hippies and the drug traffic, more concerned about school courses, and police methods. Both groups rate racism as the most important problem, with poverty, pollution, and drugs next in importancel(see table 1 , below).

\begin{tabular}{|c|c|c|c|c|}
\hline Problem & Alienated & Non-alienated & Drus user & Non-user \\
\hline Pollution & 3.99 & 4.06 & 4.09 & 3.91 \\
\hline $\begin{array}{l}\text { Recreation } \\
\text { \& Culturai }\end{array}$ & 6.43 & 6.91 & 6.56 & 6.76 \\
\hline Curfew & 7.63 & 7.79 & 7.41 & 7.82 \\
\hline Drug & 4.49 & 3.04 & 4.77 & 3.17 \\
\hline Poverty & 3.26 & 3.18 & 3.25 & 3.13 \\
\hline Racism & 2.94 & 2.85 & 2.85 & 2.86 \\
\hline School & 6.43 & 7.80 & 6.39 & 7.55 \\
\hline Traffic & 6.57 & 6.94 & 6.61 & 6.87 \\
\hline $\begin{array}{l}\text { Cong. } \\
\text { Police Wthat }\end{array}$ & 55.19 & 6.19 & 5.25 & 6.06 \\
\hline Hipries & 7.63 & 5.92 & 7.37 & 6.37 \\
\hline
\end{tabular}

Question 47 (see arpendix) asked the respondents to indicate from 1 to 10 how they rate the list of moals miven. The aljenated vant 
more to have serenity and somewhat more to have power. They also wanted less to be useful, somewhat more to have money, and less to have a close family. Both groups listed being happy first and being loved second. Having prortinence, moner, and power were rated at the bottom of the list br both. (see table 2 , helow).

\begin{tabular}{lcccc}
\hline \multicolumn{3}{l}{ Table 2, oals as rated by resnondents ranked on a l-10 scale. } \\
\hline Goal & Alienated & Non-alienated & irus user & 1on-user \\
\hline Serenity & 5.13 & 5.99 & 5.18 & 5.78 \\
Power & 8.08 & 3.53 & 7.95 & 8.57 \\
Happy & 2.78 & 2.96 & 2.80 & 2.89 \\
Useful & 4.64 & 3.97 & 4.34 & 4.16 \\
Liked & 5.37 & 5.08 & 5.34 & 5.12 \\
Admired & 6.21 & 6.10 & 6.29 & 6.10 \\
Mioney & 7.08 & 7.63 & 7.21 & 7.58 \\
Prominence & 7.43 & 7.13 & 7.39 & 7.25 \\
Close Family & 5.01 & 3.84 & 4.78 & 4.12 \\
Loved & 2.95 & 3.06 & 3.09 & 2.93
\end{tabular}

\section{DRUG USE}

The arug user is older than the non-user ( 16.93 years of age as compared with 16.57 years old), is more often male, and is inost likely to be from Charix.

He feels less favorable toward his school, the city, armed forces, the older generation, the U.S. Government, and the police than the non-user. Fe is more favorable to the hippies, and less favorable to parents, the YMCA and YrCA, end to city officials. Fe also tends 
to be less favorable to the Boy Scouts and the Girl Scouts, although not to a significant degree.

Considering the social alienation items, he is found to think that most people will not work for a better world, that what parents want their children to do is for the child's good, that most people would be better off not being born, that nobody really cares for anyone else, and that parents are always lookins for things to nag their children about.

The drug user did not have significantly different responses from those of non-users on iters relating to powerlessness and numbness.

As could be expected the drug user thinks that marijuana should be legalized and that penalties for its use or possession should be reduced.

The drug user reports that if he had a personal problem, he would talk it over with an ooposjte sex frjend rather than with a parent.

The user attends clubs less often and goes to church far less often than the non-user. Te is less likely to live at home with both parents and more likely to live independently or in a foster home. He is less likely to agree with his parents regarding his coals in life and is also likely to have moved more often in the past five years.

The user is also more likely to have been arrested, and more frequently for a drug offerse than for a traffic offense.

In terms of comunity problems, he does not consider the drug traffic or hippies as being as important a problem as does the non- 
user, and feels that school courses and police methods are more a problem. Both groups.agree on racism as the number one problem with poverty next(see table 1 ).

The user sees serenity as a more important goal than does tie non-user and is more concerned with beings a power in people's lives. A close f'amily is not considered as being as important for them. As with the alienated-non-alienated sample, being happy and being loved were most important with power, money, and prominence being least important (see table 2 ).

\section{CORLIJSIONS}

In comparins the response patterns of the alienated nerson with those of the drug user it becomes aporent that there is a himh degree of corresnondence vetween the two. soth are the oldor and more male of their comparative subsets. The average drug user's responses on the social alienation section would hove put him in the alienated subset.' 'their respective responses to the social alienation scale were also essentially identical. The alienated tended to feel leess powerful and more numb than did the user. However, the total scores for those sections was not found to discriminate between alienated-non-alienated, or user-non-user.

Both groups are in favor of Jegalized marijuana and reduced peralties, are most iikoly to talk over problews with an opositesex friend, negative toward parents, churches, and clubs and are more likely to have been arrested than non-alienated on non-user respondents. The alienated also was most likely to have used drugs 
compared to the non-alienated. Both are less likely to live at home with both parents and to agree with them regarding future goals. The alienated and the drug user are in close agreement regarding community problems and their poals as shom by tables 1 and 2 , being in agreement in 9 of 10 items on each.

THE SECOND SAMPIE

The second sample used in preparing this paper was gathered from Vocational Village and Irom John Adams High School.

John Adams was selected for the survey as it was felt to be representative of the total high school population of the city. It is a new, experimental and innovative school wich by design serves a cross-section of racial, social, and economic groups.

Adams opened in September, 1969 with approximately 1300 students, grades 9-11. This was some 200 more than had been anticipated. The student body is drawn from parts of three existing high school districts, Grant, Jefferson, and Madison, plus all or part of eight elenentary districts.

At the time of the 1960 cersus, $12 \%$ of the population in what is now the Adams district lived on under $\$ 3,000$ a year. Three of ten 1960 census tracts reported that slimtly over $20 \%$ of the families had incones over 310,000 and two others had almost $20 \%$ of the families at the $\$ 10,000$ level. The non-thite population was given as $2 \%$. School officials estimate that presently aporoximately $20 \%$ of the families fall within the Federal classification of poverty. The 
present Black student enrollment from the district is approximately $22 \%$

The philosophy, program, and organization at Adans represent a distinct departure from the traditional high school, for the primary curricular objective at Adams is to design an educational program that is relevant to the needs and interests of all students whether headed for further education or not. The aims are to break down the walls between the teaching disciplines and to develop problem-centered inter-disciplinary courses, to widen considerably the range of courses or experiences from which students can choose, and to provicie more opportunity for students to explore adult roles and bocome familiar with the working world.

The studert body at Adams is divided into four "houses," each containing some 300 randomly assigned students. Jach house is responsible for the basic skills portion of the curriculus. Fhis is taught in a three-period blocls of time called General Education. Two houses meet for General Education in the morninss and two meet in the afternoons. The rest of his day is the student's own to plan. He may take courses in which he is interested, to to the library, the student lounge, the park that is adjacert to the school, to the electronic learning center, or to a number of other study centers.

Attendance is talen once furing the dar for official record so a student may, if he chooses, cut some or all of his classes without bein counted absent from school. This is oroving to be a najor problen at Adams as clas room attendance is often poor. While the official attendance Iists show from $15 \%$ to $20 \%$ absent on any given 
day, the response to the survey indicates that only about 50\% of the students were in class and filled out the questionnaire.

At Adams the survey was administered differently than at the other hish schools in that it was done under the sunervision of the classroom teachers. This was at the request of the school.

Arrangernents were made to have questionnaires administered in one morning house and one afternoon house. One yeriod of General Education was devoted to the task and the questionnaire was filled out in ten rooms simultaneously, giving all students present that day a chance to participate. As already noted, only about ons-nalf of the students responded. Only 325 responses were received out of an anticipated approximately 600 .

Vocational Villape was selected because its program is designed to reach students who have not been successful in their previous high school experiences. Its student body is draw from all over the city and so does not represent any geographic subdivision that can be described demographically. A larger number of students live in. the Southest area of the city than in any other area, a probable result of the school's location and the limited transportation available to high school age youth.

Arrangements for taking the survey were nade with the director of the Village and with two of the academic subject teachers. The writers were able to administer the questionnaires directly to 57 students representing approxinately $50 \%$ of the then current enrollment. 


\section{ARALYSIS OF DATA}

In the second sample data were run through the computer in 5 divisions. The first was institutional alienation done in the same manner as in sample one. The second division compared those who have ever used drugs with those who had not. The third division compares the heavy user. Division four was used to compare the two schools. Iivision five compared higher social-econoric status with lower social-econamic status. The same methods of data analysis were used as in the iirst sample except that the item-by-iten comparison of responses by schools used chi-square to calculate significance for items 1,2, 4, through 39 inclusive, 41, 42, 44 through 46 inclusive, 48 through 67 inclusive, $69,70,73$, and 75.

Social-econonic class was obtained by coding auestion 71 .

(father's occupation) as follows:

1. Major executive, major professional

2. Eusiness manager, medium proprietor, lesser professional

3. Administrative personnel, small businessman, minor professional

4. Clerical, sales, techician

5. Skilled labor trades

6. Semi skilled labor

7. Unskilled labor

8. Casual labor or unemployed

Levels $1-4$ were consilered to be the upper class or subset, and $5-8$ the lower class or subset. 
THE TWO SCHOOI,S

In comparing the two schools, the Vocational Village student is considerably older (16.59, ears of ace as compared to 15.25), and is farther along in school (10.48 grade level as compared with $9.54)$

The Vocational Village student tends to have a higher opinion of his school, though not to a significant degree. He is more negative toward the U.S. Government and is decidedly more negative toward the police. He is significantly nore nerative toward churches and to the YHCS ard YWA with a concentration of responses around "don't care."

There is no simificant difference between John Adams and Vocational Village in the social alienation section although the Village student does tend to acree thet most people won't do anything to nake this a better world.

While pwerlessness and numoness scores show no simnificant oifferencés between the schools, individual items indicate somo differing attitudes. The Village" student for example, is simisicantly more likely to reject the idea that he sometimes cannot understand why he does things ond to arree that what a nerson makes out of life devends on him. Tie is also more likely to feel that not all neorle are intended to be happy in life. Iis response to "ihere are days when nothing seems to matter" is nixed, tendinm to concertrate toward mosty disagree and may from nostly asree.

whe Vocational Vilinge student is strongly in favor of marijuena and for reduced penalties for its use or nossession. He is very 
much more likely to have used all drugs, more recently, and more often than the Adams student.

The Village student goes to meetinss of clubs and organizations and to church services considerably less often. He has been arrested more often and for more serious offenses. If he has a personal problem, he is more apt to tall with an older nember of his family and less apt to talk to some other older person.

The Vocational Village student is significantly less interested in pollution as a problem then the Adams student, althougn it still does rank as the number two problem. He tends to see recreational and cultural facilities, the curfew, and police nethods as ereater problems, but not to a significant degree. Fe sees school courses as more of a problem. Soth schools rate pollution, racisn, poverty, and drugs as being very important, with hipoies, school courses, and the curfew being of lesser importance. (see tabie 3)

\begin{tabular}{|c|c|c|c|}
\hline Problem & Vocational & Village & John Adams \\
\hline Pollution & 3.61 & & 2.58 \\
\hline $\begin{array}{l}\text { Recreation } \\
\& \text { Cultural }\end{array}$ & 6.39 & & 7.01 \\
\hline Curfew & 6.83 & & 7.60 \\
\hline $\begin{array}{l}\text { Drus } \\
\text { traffic }\end{array}$ & 4.37 & . & 4.07 \\
\hline Poverty & 3.71 & & 3.26 \\
\hline Racism & 3.35 & & 2.80 \\
\hline $\begin{array}{l}\text { School } \\
\text { Courses }\end{array}$ & 6.74 & & 7.71 \\
\hline Traffic & 5.82 & & 6.47 \\
\hline $\begin{array}{l}\text { Cong. } \\
\text { Police Mthds }\end{array}$ & 5.18 & & 5.95 \\
\hline Hippies & 6.68 & & 7.23 \\
\hline
\end{tabular}


In the section on goals the Village student differs significantly in that he is more concerned with being happy and less concerned with being useful. He tends to be less concerned with having power and more being loved. Both groups rate being havny and being-loved as first or second in importance with prominence, money, and power last in that order(see table 4 , below).

\begin{tabular}{lcc}
\hline \multicolumn{2}{c}{ Tahle 4, roals as rated b. resnoweits-ranked on 2 l-10 scale. } \\
\hline Goal & Vocational Village & John Adams \\
\hline Serenity & 6.25 & 6.14 \\
Power & 8.72 & 8.20 \\
Happy & 2.43 & 3.23 \\
Useful & 5.12 & 4.14 \\
Liked & 5.17 & 4.92 \\
Admired & 5.26 & 6.35 \\
Money & 6.87 & 7.44 \\
Prominence & 6.83 & 6.96 \\
Close Family & 3.90 & 4.31 \\
Loved & 2.48 & 3.02 \\
\hline
\end{tabular}

\section{ALIENATION}

In comparing the alienated versus the non-alicnated studert from the two schools, the same scale is used as in the first sample and the same statistical methods used.

The alienated student is somewhat more Iikely to come from Vocational Village, is older (15.58 vears old as compared to 15.33), 
and is somewhat farther along in school (9.77 grade level as compared with 9.62 - not significant however). Interestingly, sex is unrelated to alienation in this sample (chi-square $=0.01)$. This contrasts with the first sample where it was found that the alienated case was significantly more likely to be a male.

The alienated student is more negative toward his school and his city. He is highly negative toward the armed forces, the U.S. Government, and to the police, the most significant response being that they are "bad." He is also negative toward teachers and other officials, the most significant response being "don't care." As can be expected, the alienated student is more favorable to hipoies than the non-alienated. He is very negative toward churches, somewhat less negative toward business and parents, "doesn't care" about the Boy Scouts or Girl Scouts, the YMCA or the YiCA. Fe is highly negative toward city oficicials.

The alienated sample receive hioher scale scorcs of powerlessness and numbness though not to a significant degree. The section measuring, feelings of powerlessness shows only one significant difference in responses. He says that when things go wrong, he is not likely to try harder. He tends to disaree with the statement that what a person makes out of life depends on himself. Among the items bearing on numbness, the alienated tend to disagree with the statement that they are sure of their feelings and, to a significant degree, feel that life is boring and that most of their experiences are not interesting.

As is expected, the alienated person is strongly in favor of legalizing marijuana and reducing penalties for use or possession. 
The alienated indicate strong social alienation in that they tend to agree that most people won't do anything to make a better world, strongly disagree that parents want things that are good for their children, tend to agree that most people would be better off not being born and that parents are always looking for things to nāg them about.

If he has a personal problem he is more likely to keep it to himself and less likely to talk it over with a parent than is the non-alienated.

The alienated roes to meetings of clubs or or panizations and to church far less frequently, his most significant response being "never."

Tie has been arrested more frequently though there is no significant difference in the seriousness of the charges compared with the non-alienated.

He reports that he is much less likely than is the non-alienated to agree with his parents regarding goals for his future.

The section on drug usage siows that he has used nore drugs, more recently, and more frequently except that there was no significant difference in response for the use of inhalants and hallucinopens in the last rear.

In the community problems section, the only sionificantly different resnonses were that the slienated are less concerned about the drum traffic and hipnies, ari are auch more concerned about, rolice methods. They are more concerned with the curfew but not simificantly. Both erouns aree in that twey rank pollution, racism, noverty, and the drug traffic in that order as the four most jmortant problems (see table 5, below). 
Table 5, community problems as reted by respondents-ranked on a 1-10 scale. Sample 2-John Adans and Vocational Villame.

\begin{tabular}{|c|c|c|c|c|}
\hline Problem & Aienated & Non-alienated & Drug user & Mon-tiser \\
\hline Pollution & 2.87 & 2.65 & 3.15 & 2.62 \\
\hline $\begin{array}{l}\text { Recreation } \\
\text { \& Cultural }\end{array}$ & 6.66 & 7.08 & 6.11 & 7.15 \\
\hline Curfew & 7.17 & 7.68 & 6.66 & $7 \cdot 71$ \\
\hline $\begin{array}{l}\text { Drus } \\
\text { Traffic }\end{array}$ & 4.74 & 3.65 & 5.66 & 3.68 \\
\hline Poverty & 3.46 & 3.21 & 3.58 & 3.26 \\
\hline Racism & 3.00 & 2.82 & 2.88 & 2.88 \\
\hline $\begin{array}{l}\text { School } \\
\text { Courses }\end{array}$ & 7.47 & 7.66 & $7 \cdot 32$ & 7.64 \\
\hline Traffic & 6.50 & 6.23 & 6.01 & 6.47 \\
\hline $\begin{array}{l}\text { Cong. } \\
\text { Folice utids }\end{array}$ & $s 4.92$ & 6.43 & 4.88 & 6.10 \\
\hline Mippies & 7.73 & 6.81 & 8.04 & 6.90 \\
\hline Table 6 & 6, moals as & rated by respon & ats-ranted on & a $1-10$ scole. \\
\hline Goal & Alienated & Mon-alienated & Drug user & Son-user \\
\hline Serenity & 6.13 & 6.21 & 6.11 & 6.17 \\
\hline Power & 7.92 & 8.55 & 7.97 & 8.36 \\
\hline Happy & 2.99 & 3.17 & 2.76 & 3.19 \\
\hline UsefuI & $4.31^{\prime}$ & 4.27 & 4.61 & 4.21 \\
\hline Liked & 5.07 & 4.91 & 4.82 & 5.00 \\
\hline Admired & 6.20 & 6.36 & 6.35 & 6.34 \\
\hline Money & 7.27 & 7.25 & 6.74 & 7.52 \\
\hline Prominence & 6.93 & 7.04 & 7.35 & 6.83 \\
\hline Close Family & $y 4.73$ & 3.98 & 4.72 & 4.11 \\
\hline Loved & 2.98 & 2.99 & 2.90 & 2.94 \\
\hline
\end{tabular}


The section on goals shows the alienated to be more concerned with power and less with having a close fanily. Both groups agreed that being loved was most important, followed by being happy. prominence, money, and power were ranked 8 th, 9 th; and 10 th in importance by both rrouns (see table 6, above).

DRUG USE

In categorizing a respondent as a drug user the criteria used is that any case who reports taking arugs six or more times is considered to be a user. These were analyzed in the trird division.

The user is older ( 15.95 years of age as co pared to 15.31), and farther along in school (10.10 grade level compared with 9.56). He is much more likely to come from Vocational Village tian from John Adams. Whe sex of the respondent is unrelated to drug usage (chi-square $=0.15$ ) unlike the first sample where users were most often males.

The user feels less favorable to the armed forces, U.S. Government, the police, parents, and city officials. He is nore favorable to the hippies. Fis attitudes toward the Boy scouts and Girl Scouts, and the IMCA and YUCA is less favorable with a noticeable trend to respond "don't care."

In the social alienation items, the user disagrees that what parents want their child to do are for the child's own food and arees thet they look for things to nag about. There is a tendency to aree that some peorle would be better off not being born. 
The user tends to agree, though not significantly so, that he is the master of his fate. He rejects the ideas that he cannot always understand why he does things and that he tries harder when thines go bad. Fhere is a tendency to arreo that some dars nothins seems to matter and there is simificant areement that most of life is boring.

As expected, he is stroncly in favor of legalizin marijuana and reducins the penalies for its use or nossession.

Apersonal problen is very likel: to be kent to himself and very unlikely to be talked over witi a narent.

He is less likely to go to metings of clubs or orranirations or to so to church then is the non-user. He has moved nore frecuently and is somewhat less likely, to live with both narents. Arrests are more comon among users and more are for drus chares and felonies than amone non-users.

The user sees the lack of recrestional and cultural opportunities, the curfew, and police methods es oreater problems than does the non-user. Tipoies and the drug traffic are seen as less of a problem. Both roups rate racism, pollution, and poverty lst, 2 nd, and $3 r d$ in that order(see table 5, above).

The user's goals differ from the non-users in that he is simificantly more interested in having money and less interested in beins a proininent person. He is somewhat more concerned with happiness and somenhat less concerned with having a close farily. With both proups, being loved and being happy are most important, and noney, prominence, and power are least important. 
THE HEAVY DRUG USER

Division 2 compared the heavy (see p.19) drug user with the occasional or one time user.

The heavy user was found to be somewhat older, farther along In school, and more likely a male than the occasional user, but he did not otherwise differ significantly.

Therefore, it can be said that the extent of drug use does not seem to be related to the degree of alienation as measured by this survey. For the balance of the paper, when the term "user" is used, both the heavy user and the occasional user are included in the meaning. 


\section{SOCIO-ECONOHTC STATUS}

Division 5 formed two subsets based on the father's occupation (see page 12 for explanation). The purpose was to attempt to determine whether or not there is a relationship between socio-economic class and alienation or drug usage.

The lower class respondent is somewhat older( 15.54 years old as compared with 15.34 - not significant), slightly farther in school (9.77 srade compared with 9.58 - also not significant) and is more likely to be from Vocational Village. Sex is not related to class in this sample.

There were no significant differences with regard to institutional alienation although there was a terdercy to be less positive to the school and to be more positive toward the U.s. Government. The social alienation items likewise revealed no simnificant differences. There was a tendency for the low sroup to agree that most people won't do anything to make a better world and that most people would be better off not being born. Whe low groun did have a simnificantly hicher (more alienated) rating or the total social alienation scale.

The lov sroup aprees that wat a person makes of his life ceponds on him ard shat getting wat you want js mortly a matter of etting the breaks. Whey also tond to reject the inea that some penole are intenced to bo hopy and others aren't. They also see Iife as boring.

The low income person is less concerned with nolution and tends to be less concerned with the drus traffic. He is less 
concerned wjth being useful and more concerned with havine a close family.

He is less likely to go to meetings of clubs or ormanizations and has been arrested more frequently than a higher staius nerson.

There were no significant differences under drug usage althourh the low status person did tend to use amphetamines, opiates, and harbiturates more often.than a higher status person. 


\section{CONCLUSIONS}

As with the first sample there is a strong similarity of the profile of the drug user compared with that of the alienated.

Both the alienated and the drug user are older than the nonalienated and the non-user, and are farther in school. Unlike the first cample, the sex of the respondent was not a factor.

In the items measuring alienation, the drug user's responses would put him in the alienated subset. Most responses to other items are essentially similar from one to the other.

Both are negative toward the armed forces, U.S. Government, the police, parents, and city officials. As expected, both are favorable to the hippies. They tend to not care about Boy and Girl Scouts, and the YMCA and FWCA.

They agree that parents look for things to nag them about, that what parents want their children to do are not for the child's own good, and that most poople would be better off not being born. Life is seen as boring and most experiences are not considered to be interesting.

Neither is likely to go to church or to attend meetings of clubs or other organizations, or to have lived in the same house for the past five years, or if they have personal problems, to talk to anjone about them. Both are more likely to have been arrested than the others in the survey.

Both are highly in favor of legalized marijuana and reduced penalties for its use. They do not consider that hippies or the drug traffic are as important as problems than do the others. 
Police methods, pollution, racism, and poverty are the most important problems in their eyes.

Their goals are similar in that they are less concerned with having a close family and more concerned with being happy and being loved. Having money and being prominent are not seen as being very important goals.

Overall, the drug user - alienated youth seems to be a socially isolated individual who is very negative toward parents and their values, and rejects most of what the older generation accepts, and accepts activities and values that are rejected or not stressed by them as being important. It is interesting that in both samples, being happy and being loved were far more important than money, power, and prominence, the latter seemingly being the older generation's goal at the expense of the former.

The attitudes of those in the low sociomeconomic status cases seem to be closely parallel to those in the alienated and drug user cases. They too, are older and somewhat farther along in school and seem to beisocially isolated. This suggests a relationship between low status, drug use, and alienation. This would be consistent with the study by Gottleib referred to in Part I.

It should be stressed that while the attitudes of the low status person differ from those of the high status person, there is not a great difference in the use of drugs. He does tend to use amphetamines, opiates, and barbiturates more than the high status person but not to a significant degree. It can only be speculated as to whether this is a choice of preference or of economics. 
If we are to understand the phenomenom of alienation and so be able to deal with it constructively, we must be able to isolate, study, and understand the factor or factors causing alienation. This study has pointed out some characteristics of the alienated. Whether or not these characteristics are causes or symptoms is not shown and should provide the basis for future more intesive studies.

It is striking that in each of the several schools and at Charix that the alienated, the drug user, and the low socio-economic status person was older and farther along in school than was the comparative case. The school progress seems naturally to follow from the age factor however, there is an implication that alienation and drug use result from some factor in the growing up process. The relationship of status is not clear.

The family relationships in this group are shown to be less farorable, than appears to be the case for the non-alienated, nonuser. They feel that parents are not looking for what is good for their children, they nag them, do not agree on goals, and that they cannot talk to them about personal problems. It is significant also that the alienated and the user is less likely to live at home with both parents, to have moved more often, and that he places less value on having a close family. There is an obvious need to determine what happens in a family to cause such a reaction in the children. We also need to learn what can be done about it. Realistically, much is already known about the causes, solutions are the difficulty. 
The alienated are bored with life and quite cynical about what people will do to improve conditions. They thembelves, say that when things go bad they don't try harder. Coupled with their rejection of institutions these attitudes would seem to provide a basis fon unrest such as we see today. They seem not to see any way to improve conditions through the normal avenues of change set up by our society.

Rejection of the norms and values of the older generation is not confined to the alienated. As shown by tables 2 and 6 , money, power, and prominence are rejected by all the respondents. Being happy and being loved are their major goals. The problems they are concerned with are racism, poverty, pollution, and the drug traffic. Culture and recreation, and school courses don't rate very high. (tables 1 and,5)

It would appear from this that the young are as a whole, highly idealistic, which is to be expected. At the same tine they seem to reject those goals which society tends to equate with the ability to gain influential positions. The problems that they see as being most important are ones which depend upon action by the older generation for solution, yet they see the older generation as being unlikely to do anything about it.

Alienation of the young has been the concern of the older generation in almost every generation. Many examples can be cited from the past wherin dire warnings are given regarding the "disasterous" behavior or the young. This should not be allowed to dilute the concern for the present. The most alienated possess the capacity 
for deviant means of expression, including violence and confrontation. The current activities on and around various colieges are prime examples. This survey reveals that not only the alienated reject much of what our society offers but so do the non-alienated. We cannot pass this off as being just like everyother generation. No other jounger generation has possessed the capacity and resources for deviant behavior as has this one and none has been so well publicized when it did act.

Somehow the older generation must come across to the young as being concerned with their goals and ralues and as willing to sit down with them and seek solutions. At present the use of the police seems inappropriate. The police are used by society to protect some of the very values and ideals which the young reject.

The older generation needs to look at itself and to determine what it was about itself that created today's younger generation. Then it must take the responsibility upon itself to deal with what It has created.

It should also be realized in studying the results of this survey that the most alienated in our city are probably not in school and, if they were, probably would not participate in a survey designed and administered by the "power structure." 
APPENDIX

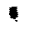




\section{METROPOUITAN YOUTH COMMISSION QUESTIONNAIRE}

This questionneire is designed to find out what different young people think of the world and their part in it. It asks questlons about you and your altitudes. We don't need to know your names on these questionnatres; they are completely anonymous. However, we would like to have you answer them frankly and seriously. Our object is to report to the community what Portland's young people think and want. Your cooperation will help us in this fob.

Don't put your name on the questionnalre. Try to answer each question frankly and truthfully. If you heve any questions, ask the person who is giving the test. We'd welcome your comments if you would write them at the end or in the margins.

1. Your Age

2. Your Sex

Male

Fomsle

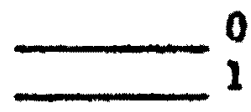

3. How far have you gone in school? (Glve grade completed or years of college)

4. Race

Mits

Blank

cricntal

otiser

there are some things that acher .eel differently about. Show how you feel about each by checking one blank on the right for each item.

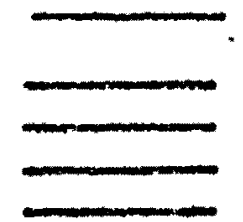

5. Your school

Good

Somewhst good

Don't care

Somewhat bad

Bad

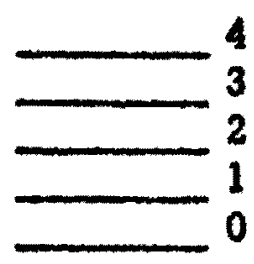

6. Your city
Good

Somewhat good

Don't cere

Somowhat bad

Bad

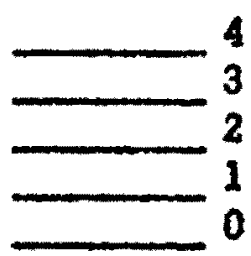


Metropolitan Youth Commisston 2uestlonnalre

Poge 2

7. Tha Armed Forces

Good.

Somewhat good

Don't care

Somewhat bad

Bad

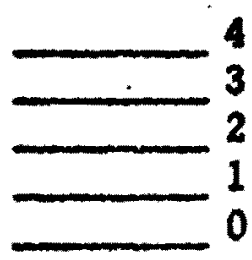

8. Sobool Taschere and

Cood

Other officials

Somewhat good

Don't care

Somewhat bad

Bad

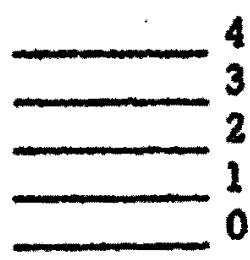

9. U.S. Government

Good

Somewhat good

Don't care

Somewhat bad

Bad

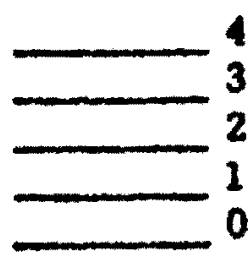

10. The Police

Good

Somowbet good

Don't caro

Somewhat bad

Bad

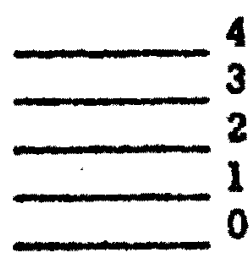

11. Hipples

Good

Somewhat good

Don't care

Somewhat bad

Bad

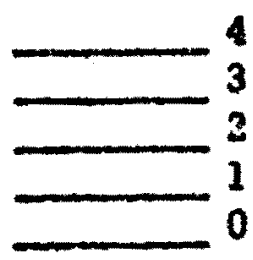

12. The churches

Good

S=mewhat good

Dor'is caro

Somowñ: bad

Des

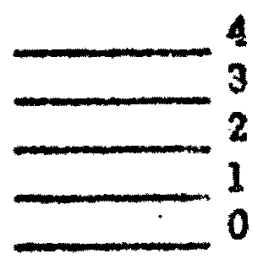

13. Business and Industry

Grod

Sonterwisyt good

Don's, core

Soses:usi bad

Bad

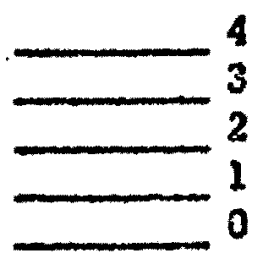


Metropolitan Youth Commlssion Questionsistre

Page 3

14. Your parents

Good
Somewhat good
Don't cere
Somewhat bad
Bad

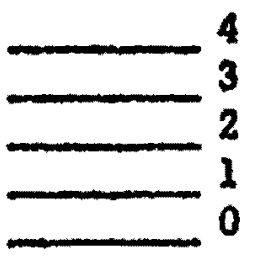

15. Boy Scouts and Gtrl Scouts

Good

Somewhat good

Don't care

Somewhat bad

Bad

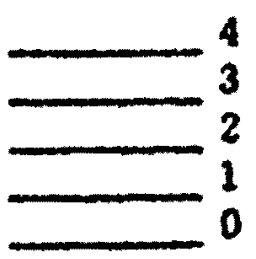

16. YMCA - YWCA

Good

Somewhat good

Don't care

Somewhat bad

Bad

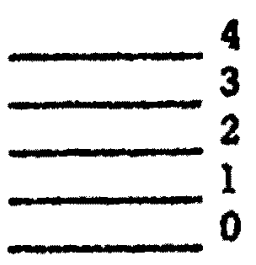

17. City offictals

Good

Somewhat good

Don't care

Somewhat bad

Bad

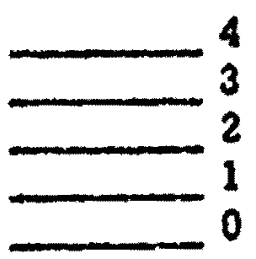

Here are some statements representing common attitudes. Please check to show whether or not you agree with them.

18. I am the master of my fate.

Completely Agree

Mostly Agree

Mostiy Disagree

Completely Disagree

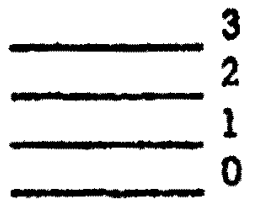

19. Sometimes I can't understand why I do the things I do.

Completely Agree Mostly Agree

Mostly Disagree

Completely Disagree

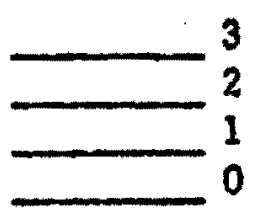

20. What a person makes of hls life depends on him.

Completely Agree Mostly Agree

Mostly Disagreo

Completely Disagree

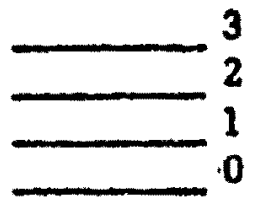

21. Gotting what you want is mostly a matter of getting the breaks.

Completely Agree Mostly Agree Mostly Disagree Completely Disagree

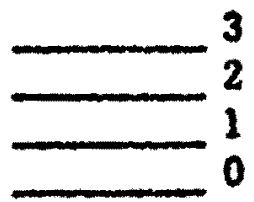


Metropolitan Youth Commission questionnatre

Page 4

22. There are days when nothing seems to matter.

Completely Agree

Mostly Agrso

Mostly Disagree

Completely Disagree

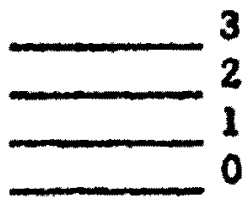

23. I am sure of my feelings about

Completely Agree things that affect my life.

Mostly Agree

Mostly Disagree

Complately Disagree

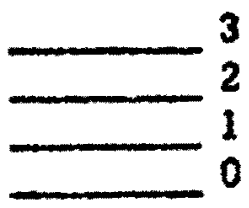

24. In life, some people are Intended Completely Agree to be happy, others aren't.

Mostly Agree

Mostly Disagree

Completely Disagrea

25. Most of life is pretty boring.

Completely Agree

Mostly Agree

Mostly Disagree

Completely Disagree

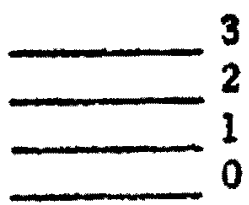

Completely Agree

Mostly Agree

Mostiy Disagrea

Completely Dlsagree

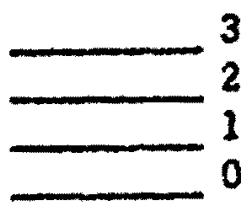

26. When things go bad, I try harder.

Completely Agree

Mostly Agree

Mostly Dissgree

Completely Dtsagree

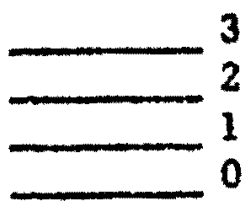

27. Most of my experlences are Interesting oncs.

Completely sgree

Mostly Agree

Mostly Disagree

Completely Disagree

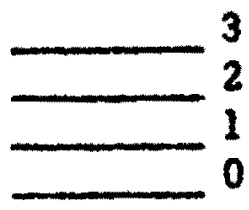

28. Most people won't really do anything to maks this a better worid.

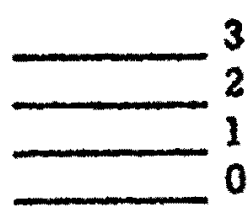

29. Things parents want thelr cinild to do are for the chlld's own good.

Completely Agree Mostly Agree Mostiy Disagree Completely Disagree

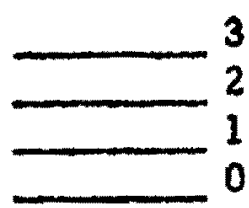

30. With things as they are, most people would be better off if they were never born.

Completely Agree Mostly Agree Mostly Disagree Completely Disagree

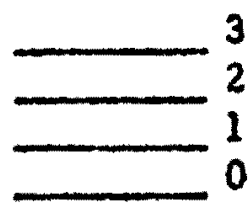


Metropolitan Youth Commission Questlonnaire

Page 5

31. Nobody really cares about anyone else.

Completely Agree

Mostly Agree

Mostly Disagree

Completely Disagree

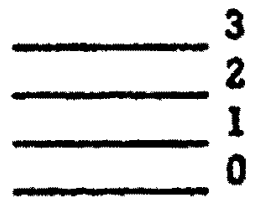

32. Parents are always looking for Completely Agree things to nag their chlldren about. Mostly Agree

Mostly Disagree

Completely Disagree

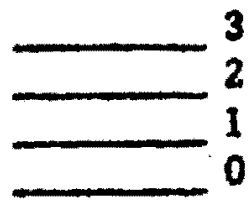

33. Martjuana should be legallzed. Completely Agree

Mostly Agree

Mostly Disagree

Completely Disagree

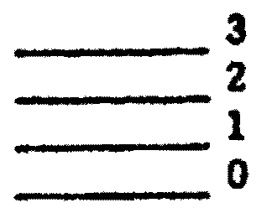

34. Smoking or possession of marifuana should be considered

Completely Agree

a misdemeanor instead of a felony.Mostly Disagree

Completely Disagree

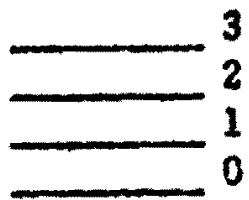

35. If you had a personal problem, which of the following people would you be most likely to talk it over with?
A parent
Frlend of your own age and sex
Friend of your own age of opposite sex
An adult outside the family
Wouldn't talk it over with anyone

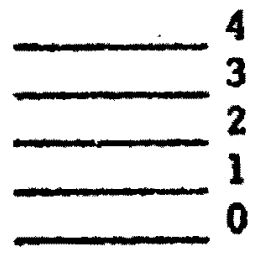

36. How often do you attend meetings Never of clubs and organlzations?

Rarely

Once a month

Once a week

More often

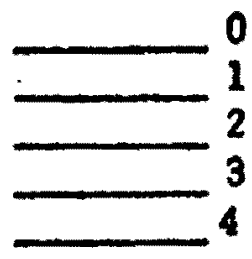

37. How often do you go to church? Never

Rarely

Once a month

Once a week

More often

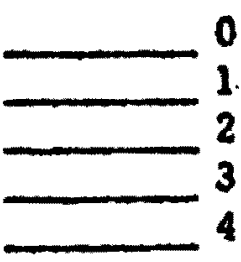

38. Where do you live?

At home with both parents

At home with a parent

With spouse

Independently (boarding house, apt. etc.)

Other (Institutions, foster home)

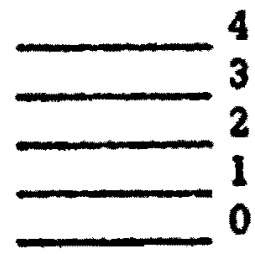


Metropolltan Youth Commission Questionnaire

Page 6

39. How many times have you moved in the past fivo years?

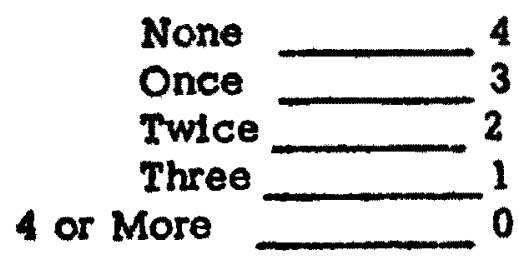

40. Different people in school and out Identify themselves with different groups. Which of the following groups do you Identify with? (Check only one)

Squares
Hipples
Straights
Hypes
Soshes
Hoods
Brains
Wheels
Leftists
None of these

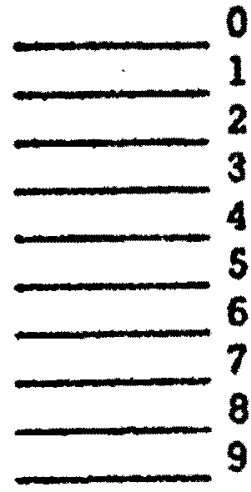

41. Have you ever been arrested?

Yes

No

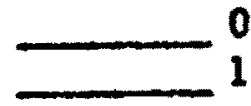

42. What for?

43. Here are some problems our community has. Show how Important you feel they are by putting 1 along side the most urgent problem and continue numbering unt1l you get to 10 opposite the least Important problem:

Pollution

Lack of recreation and cultural events

The curfew

Drug traffic

Poverty
Racism

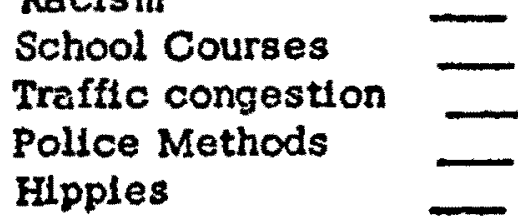

44. If there are other problems you feel important, enter them here and indicate by a number how they would rank in comparison with the problems above.

45. What public figure in your 11 fettme have you most admired?

46. Among the people you know personally, whom do you most admire? (Don't glve the person's name but Identify his relation to you -- boyfriend, older sister, doctor, teacher, etc. 
Metropolitan Youth Commission Questionnairo

Page 7

17. Different people have differont goals. Hete are some possible ones. Indicato by sumboring fium 1 to 10 how these different goals stack up for you.
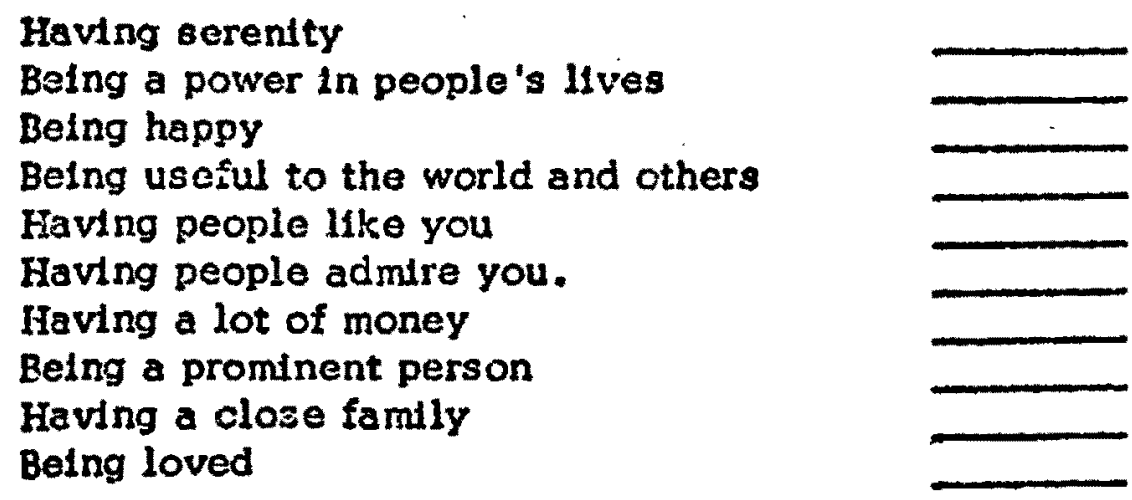

1A. Heio aro some drugs some people use for "klcks." What has your experience been with them? If you have never used any, chouh tisio And skip to question $\$ 71$. If you havo used a ding, answer $\$ 49-70$.

49. Have you ever used marljuana? Yes

No

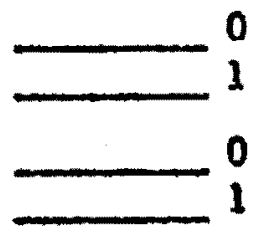

51. How extensive has that recent None use been?

Once

2 - 5 times

6 - 10 times

more often

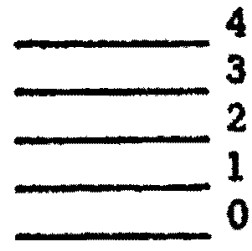

52. Have you ever used Inhalants (glue, solvents, gasoline)?

\section{Yes \\ No}

53. Have you used them in the last Yes year?

No

None

Once

2 - 5 times

6 - 10 times

more often

Yes

No or "speed")

56. Have you used them in the last Yes year?
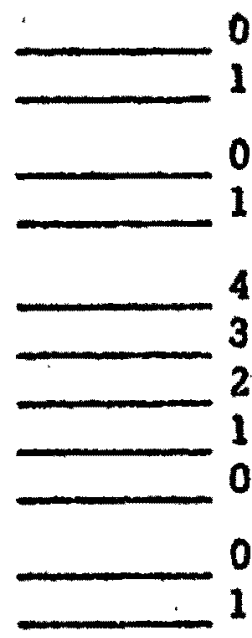

\section{0}


Metropolitan Youth Commission Questomnatre

Pago 8

57. How extenslve has that recent None use been?

$$
\begin{aligned}
& \text { Once } \\
& 2-5 \text { times } \\
& 6 \text { - } 10 \text { times } \\
& \text { more often }
\end{aligned}
$$

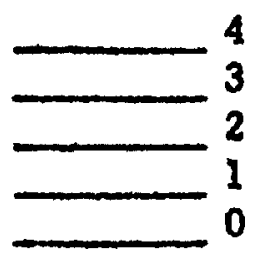

58. Have you ever used unprescribed barblturates like Seconsl, Nembutal, "rods, " or "yellows"

59. Have you used them in the last year?

\section{Yes}

No

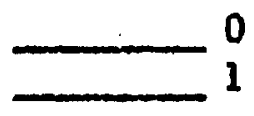

Yes
No
None
Once
$2-5$ times
$6-10$ times
more often

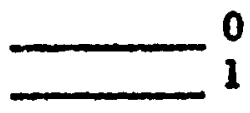

60. How extenslve has that recent None use been?

Yes

No

Yes

No

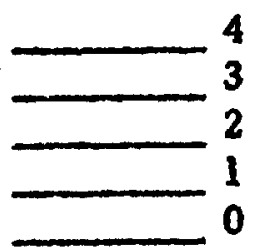

61. Have you ever used halluctnogens like ISD, mescallne, STP?

62. Have you used them in the last year?

None

Once

2 - 5 timos

6 - 10 times

more oiten

64. Have you ever used unprescrtbod oplates like heroln, momitine, Demerol, Dllaudid, Yes Codaine pllls, cocieina cough syrup?

65. Have you used it in the last year?

Yes

No
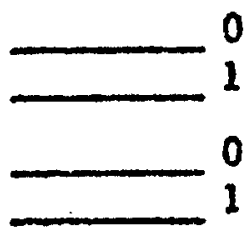

63. How exten
use been?

$\quad$ Yes
No
None
Once
2 - 5 times
6 - 10 times
more often

66. How extensive was that recent use? None

No
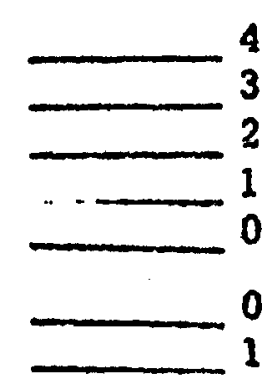
Metropolitan Youth Coinmission Questlonnatre

Page 9

70. How extensive was that recent

None use of unprescribed oplates?

Once

2 - 5 times

$6-10 \mathrm{times}$

more often

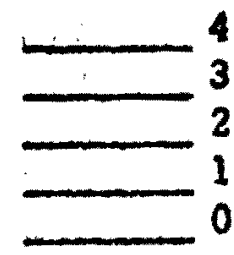

71. What kind of work does your father do? (Describe what he does, not the company or institution he works for.)

72. If your mother works, what is her occupation?

73. If you work, what is your job?

74. How many hours do you work each week?

75. Do you and your parents see eye Yes, completely to eye on goals for your future? We agree on most goals Agree on some, disagree on others Disagree on most goals Completely disagree

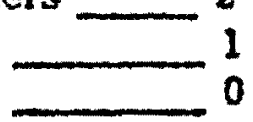

76. If you were the mayor of this city, what things would you do to make It a better place for young people to live?

77. Wo hope you have answered truthfully, if not check here 